
\title{
$\begin{array}{ll}\text { Research Square } & \begin{array}{l}\text { Preprints are preliminary reports that have not undergone peer review. } \\ \text { They should not be considered conclusive, used to inform clinical practice, } \\ \text { or referenced by the media as validated information. }\end{array}\end{array}$
}

\section{Secreted Protein Markers in Oral Squamous Cell Carcinoma (Oscc)}

Madiha Mumtaz

University of the Punjab

Irene V Bijnsdorp

VU University Medical Centre Amsterdam: Amsterdam UMC Locatie VUmc

Franziska Böttger

VU University Medical Centre Amsterdam: Amsterdam UMC Locatie VUmc

Sander R Piersma

VU University Medical Centre Amsterdam: Amsterdam UMC Locatie VUmc

Thang V Pham

VU University Medical Centre Amsterdam: Amsterdam UMC Locatie VUmc

\section{Samiullah Mumtaz}

Shalamar Medical and Dental College: Shalimar Medical and Dental College

\section{Ruud H Brakenhoff}

VU University Medical Centre Amsterdam Department of Otolaryngology Head \& Neck Surgery: Amsterdam UMC Locatie VUmc Afdeling KNO-hoofdhalschirurgie

Muhammad Waheed Akhtar

University of the Punjab School of Biological Sciences

Connie R Jimenez ( $\nabla$ c.jimenez@vumc.nl )

Vrije Universiteit Amsterdam https://orcid.org/0000-0002-3103-4508

\section{Research}

Keywords: Proteomic quantification, Secretome, Oral squamous cell carcinoma, Public biofluid datasets, human salivary proteome

Posted Date: October 18th, 2021

DOI: https://doi.org/10.21203/rs.3.rs-951335/v1

License: @ (i) This work is licensed under a Creative Commons Attribution 4.0 International License. Read Full License

Version of Record: A version of this preprint was published at Clinical Proteomics on February 8th, 2022. See the published version at https://doi.org/10.1186/s12014-022-09341-5. 


\section{Abstract \\ Background}

Oral squamous cell carcinoma (OSCC) is a main cause of oral cancer mortality and morbidity in central south Asia. To improve the clinical outcome of OSCC patients, early detection markers are needed, which are preferably non-invasive and thus independent of a tissue biopsy.

\section{Methods}

In the present study, we aimed to identify robust candidate protein biomarkers for early OSCC diagnosis. To this end, we measured the global protein profiles of OSCC tissue lysates to matched normal adjacent mucosa samples $(n=14)$ and the secretomes of nine HNSCC cell lines using LC-MS/MS-based proteomics.

\section{Results}

A total of 5,123 tissue proteins were identified, of which 205 were robustly up- regulated ( $p$-value $<0.01$, fold change $\varangle+2$ ) in $0 S C C$-tissues compared to normal tissues. The biological process "Secretion" was highly enriched in this set of proteins. Other upregulated biological pathways included "Unfolded Protein Response", "Spliceosomal complex assembly", "Protein localization to endosome" and "Interferon Gamma Response". Transcription factor analysis implicated Creb3L1, ESRRA, YY, ELF2, STAT1 and XBP as potential regulators. Of the 205 upregulated tissue proteins, 132 were identified in the cancer cell line secretomes, underscoring their potential use as non-invasive biofluid markers. To further prioritize our candidate markers for non-invasive OSCC detection, we integrated our data with public biofluid datasets including OSCC saliva, yielding 25 candidate markers for further study.

\section{Conclusions}

We identified several key proteins and processes that are associated with OSCC tissues, underscoring the importance of altered secretion. Cancer-associated OSCC secretome proteins present in saliva have potential to be used as novel non-invasive biomarkers for the early diagnosis of OSCC.

\section{Introduction}

Oral cancers are among the most frequent malignancies of the neck and head. A major oral cancer type with high mortality and morbidity is OSCC. OSCC is the 6th most common epithelial malignancy world-wide. Therefore, OSCC is a global growing concern for public health (1).

The main risk factors related to HNSCC development are use of smokeless tobacco products, chewing/smoking tobacco, genetic predisposition, alcohol consumption and/or infections with human papilloma virus (HPV). In Pakistan, Taiwan, India and China several social behaviors, such as chewing raw tobacco, gutka, paan (betel quid), chaliya (areca nut), manpuri and niswar are among common addictions. ${ }^{(2)}$ Diagnostic care includes clinical examination of the oral mucosa and histological evaluation of tissue biopsies However, these methods in general lead to a late diagnosis of OSCC. Therefore it is important to develop new non-invasive diagnostic tools that can detect the presence of OSCC at an early stage.

To identify new biomarkers that can improve the diagnosis of OSCC, analysis of global protein expression and secretion using mass spectrometry has gained increasing interest.(3) Global identification of altered expression of proteins in OSCC tissues may provide an unbiased approach to find vital biological pathways, leading to improved understanding of the primary molecular mechanism responsible for disease development and progression. Non-invasive markers may be best identified using biofluid analysis, yet plasma proteomics has been hampered, mainly because of the vast complexity and great dynamic range. To overcome this challenge, cancer cell and tumor tissue secretome analysis have emerged as alternative approaches to identify candidate tumor serological markers $(4,5)$.

Recently, the power of clinical proteomics was shown in a large scale analysis of 66 HNSCC tumors(6). Comparison to paired normal adjacent tissues revealed profound alterations in multiple biological processes such as downregulation of platelet degranulation, acute inflammatory response, fatty acid metabolic process and muscle system process and upregulation of protein hydroxylation, leukocyte migration, cell chemotaxis, and angiogenesis(6).

In this study, we set out to identify "non-invasive" protein biomarker candidates that can be detected in oral cancer-relevant biofluids. To this end, we employed mass spectrometry-based proteomics, to examine protein expression profiles in OSCC and adjacent normal tissue along with analysis of secretomes of nine HNSCC cell lines. To further prioritize our candidate markers for non-invasive OSCC detection, we integrated our data with public biofluid datasets: salivary proteome healthy vs. OSCC dataset by Chu et al., 2019 (7), Human salivary proteome by P. Sivadasan et al., 2015 (8) and available Normal Saliva Proteome database (https://salivaryproteome.nidcr.nih.gov/). Moreover, we also describe oral cancer associated biological pathways and TFs involved in regulating those proteins to gain understandings of differential biology of secretion.

\section{Materials And Methods}

\section{Collection of tissue specimen of OSCC patients}

This study includes 14 patients; Tissue samples of male and female subjects diagnosed with oral squamous cell carcinoma (OSCC) were collected from local Hospital Lahore, Pakistan according to the approved guidelines of the Ethical Review Committee of the King Edward Medical University [Ref. No. 306/RC/KEMU] with consent of the patients (Table 1). Patients suffering from either Hyperplasia, Papilloma, Pleomorphic Adenoma, Soft Tissue Tumor, 
Odontogenic tumors, HIV infection, hepatitis C, B and/or with history of current or earlier chemotherapy or radiotherapy were excluded from the investigation. According to AJCC recommendation surgeons performed TNM Staging of OSCC tumors. After surgery tissue specimens (tumor and adjacent non-tumor tissue) were immediately frozen in liquid nitrogen and stored at $-80^{\circ} \mathrm{C}$ for future use. No cancer cells in non-tumor tissues and around $80 \%$ cancer cells in all resected tumor tissues were revealed by pathological evaluation. Clinical information of patients was collected including medical history and demographic data.

Table 1 Clinical information of the study subjects

\begin{tabular}{|c|c|c|c|c|c|c|c|c|c|c|c|}
\hline $\begin{array}{l}\text { Serial. } \\
\text { No }\end{array}$ & $\begin{array}{l}\text { OSCC } \\
\text { Patients }\end{array}$ & Sex & Age & $\begin{array}{l}\text { Family } \\
\text { History }\end{array}$ & $\begin{array}{l}\text { Clinical } \\
\text { Presentation }\end{array}$ & $\begin{array}{l}\text { Tumor } \\
\text { Localization }\end{array}$ & $\begin{array}{l}\text { Histological } \\
\text { Diagnosis* }\end{array}$ & $\begin{array}{l}\text { Staging } \\
\text { TNM }\end{array}$ & Smoking/Tobacco & $\begin{array}{l}\text { Pan, Gutka, } \\
\text { Chalia } \\
\text { Chewer }\end{array}$ & $\begin{array}{l}\text { Unhealthy } \\
\text { nutrition } \\
\text { (Spices, } \\
\text { Alcohols } \\
\text { etc) }\end{array}$ \\
\hline 1 & ST1 & $\mathrm{M}$ & 70 & No & $\begin{array}{l}\text { lesions with } \\
\text { raised } \\
\text { exophytic } \\
\text { margin }\end{array}$ & $\begin{array}{l}\text { Buccal } \\
\text { Mucosa }\end{array}$ & 3 & $\begin{array}{l}\text { Stage IVA } \\
\text { (T4aN1M0) }\end{array}$ & smoking & No & Alcohol \\
\hline 2 & MT1 & $\mathrm{M}$ & 62 & No & $\begin{array}{l}\text { Ulcerative } \\
\text { type lesion }\end{array}$ & Tongue & 3 & $\begin{array}{l}\text { Stage IVA } \\
\text { (T4aN1M0) }\end{array}$ & No & Gutka & Alcohol \\
\hline 3 & ET & $\mathrm{M}$ & 60 & No & $\begin{array}{l}\text { Ulcerative } \\
\text { type lesion }\end{array}$ & Tongue & 1 & $\begin{array}{l}\text { Stage II } \\
\text { (T2NOMO) }\end{array}$ & Huka & No & No \\
\hline 4 & ST2 & $\mathrm{M}$ & 55 & No & Lump & $\begin{array}{l}\text { Buccal } \\
\text { Mucosa }\end{array}$ & 2 & $\begin{array}{l}\text { Stage III } \\
\text { (T2N1M0) }\end{array}$ & smoking & - & No \\
\hline 5 & MT2 & $\mathrm{F}$ & 40 & No & $\begin{array}{l}\text { Ulcerative } \\
\text { type lesion }\end{array}$ & $\begin{array}{l}\text { Molar area } \\
\text { (Mandibular } \\
\text { Retromolar } \\
\text { Area) }\end{array}$ & 3 & $\begin{array}{l}\text { Stage IVA } \\
\text { (T4aNOM0) }\end{array}$ & No & Pan/Chalia & Alcohol \\
\hline 6 & NT & $\mathrm{M}$ & 51 & No & $\begin{array}{l}\text { Lichen } \\
\text { planus }\end{array}$ & $\begin{array}{l}\text { Buccal } \\
\text { Mucosa }\end{array}$ & 2 & $\begin{array}{l}\text { Stage IVA } \\
\text { (T4aNOM0) }\end{array}$ & No & Paan & No \\
\hline 7 & BT & M & 38 & No & $\begin{array}{l}\text { Ulcerative } \\
\text { type lesion }\end{array}$ & Tongue & 3 & $\begin{array}{l}\text { Stage IVA } \\
\text { (T4aNOM0) }\end{array}$ & smoking & No & No \\
\hline 8 & AT & M & 45 & No & $\begin{array}{l}\text { Lichen } \\
\text { planus }\end{array}$ & $\begin{array}{l}\text { Buccal } \\
\text { Mucosa }\end{array}$ & 3 & $\begin{array}{l}\text { Stage IVA } \\
\text { (T4aN1M0) }\end{array}$ & smoking & $\begin{array}{l}\text { Pan \& } \\
\text { Gutka }\end{array}$ & No \\
\hline 9 & MT3 & $\mathrm{F}$ & 65 & No & $\begin{array}{l}\text { Ulcerative } \\
\text { type lesion }\end{array}$ & Hard Palate & 3 & $\begin{array}{l}\text { Stage III } \\
\text { (T3NOMX) }\end{array}$ & No & $\begin{array}{l}\text { Pan \& } \\
\text { Gutka }\end{array}$ & No \\
\hline 11 & ANT & $\mathrm{M}$ & 36 & $\begin{array}{l}\text { Yes } \\
\text { (Father) }\end{array}$ & $\begin{array}{l}\text { Ulcerative } \\
\text { type lesion }\end{array}$ & $\begin{array}{l}\text { Molar area } \\
\text { (Mandibular } \\
\text { Retromolar } \\
\text { Area) }\end{array}$ & 2 & $\begin{array}{l}\text { Stage IVA } \\
\text { (T4aN2M0) }\end{array}$ & Tobacco chewer & No & No \\
\hline 12 & JT & $\mathrm{M}$ & 35 & No & $\begin{array}{l}\text { Mixed } \\
\text { ulcerative \& } \\
\text { exophytic } \\
\text { lesion }\end{array}$ & $\begin{array}{l}\text { Buccal } \\
\text { Mucosa }\end{array}$ & 3 & $\begin{array}{l}\text { Stage IVA } \\
\text { (T2N2M0) }\end{array}$ & smoking & Chalia & No \\
\hline 13 & GT & $\mathrm{F}$ & 30 & $\begin{array}{l}\text { Yes } \\
\text { (Mother) }\end{array}$ & $\begin{array}{l}\text { Lesions with } \\
\text { raised } \\
\text { exophytic } \\
\text { margin }\end{array}$ & Tongue & 2 & $\begin{array}{l}\text { Stage III } \\
\text { (T3NOMO) }\end{array}$ & No & Chalia & No \\
\hline 14 & NOT & $\mathrm{F}$ & 55 & No & $\begin{array}{l}\text { Verrucous } \\
\text { type lesion }\end{array}$ & Lip & 3 & $\begin{array}{l}\text { Stage IVA } \\
\text { (T4aNOM0) }\end{array}$ & huka & No & No \\
\hline
\end{tabular}

Note: *1. Poorly Differentiated SCC, 2. Moderately Differentiated SCC, 3. Well Differentiated SCC. ¥ 1. Low scioeconomics status, 2. Middle scioeconomics status, 3. Upper scioeconomics status

\section{Tissue lysis and protein extraction}

As mentioned previously (9), $200 \mathrm{mg}$ of the tumor tissue and control tissue samples were homogenized with liquid nitrogen in a pestle with mortar, suspended in modified chilled lysis buffer, vortexed for 1 hour and centrifuged for 90 minutes at $1400 \mathrm{rpm}$ at $4{ }^{\circ} \mathrm{C}$ (Eppendorf Centrifuge, 5417R). The resultant supernatant was aliquotted and stored at $-80^{\circ} \mathrm{C}$. Bradford assay (10) with bovine serum albumin (BSA) as reference was used for estimating protein concentration in tissue lysates.

\section{Cell line cultures}


Dulbecco's modified Eagle's medium (DMEM) containing 5\% fetal calf serum (FCS), 2 mM L-glutamine and antibiotics was used to culture all cell lines (Table 2) used for this study (11). Cultures were maintained with $5 \% \mathrm{CO}_{2}$ at $37 \llbracket \mathrm{C}$ in a humidified atmosphere. HNSCC cell lines UM-SCC-22A, UM-SCC-6, UM-SCC-11B were obtained from Thomas Carey (University of Michigan, USA). FaDu cells were purchased from ATCC (12) and cell lines VUSCC-120, VU-SCC-1131, VU-SCC096, VU-SCC-040 were previously established at the Amsterdam UMC location VUmc, The Netherlands $(13,14)$. In addition, all cell lines were tested daily for mycoplasma (Mycoalert, Lonza, Verviers, Belgium). Cell lines were verified by TP53 sequencing and PCR profiling. Through GP5+/6+ DNA PCR the status of HPV was confirmed (15).

Table 2 Panel of HNSCC cell lines

\begin{tabular}{|c|c|c|c|c|c|}
\hline \multicolumn{2}{|c|}{ Human HNSCC Cell lines } & \multirow{2}{*}{$\begin{array}{l}\text { Gender } \\
\text { Female }\end{array}$} & \multirow{2}{*}{$\begin{array}{l}\text { Stage } \\
\text { T3NO }\end{array}$} & \multirow{2}{*}{$\begin{array}{l}\text { Primary tumor site } \\
\text { Tongue }\end{array}$} & \multirow{2}{*}{$\begin{array}{l}\text { HPV status } \\
\text { Negative }\end{array}$} \\
\hline HPV-NEG HNSCC & VU-SCC- $040^{a}$ & & & & \\
\hline & VU-SCC-11B ${ }^{\ddagger}$ & Male & $\mathrm{T} 2 \mathrm{~N} 2 \mathrm{a}$ & Supraglottic larynx & Negative \\
\hline & UM-SCC-22A & Female & T2N1 & Hypopharynx & Negative \\
\hline & UM-SCC-6 & Male & T2NO & Base of tongue & Negative \\
\hline & VU-SCC-120 & Female & T3N1 & Tongue & Negative \\
\hline & VU-SCC-096 & Male & T4N1 & Retromolar trigone & Negative \\
\hline & $\mathrm{FaDu}^{\mathrm{b}}$ & Male & NA & Hypopharynx & Negative \\
\hline \multirow[t]{2}{*}{ FA-HNSCC } & VU-SCC-1604 & Female & NA & Tongue & Negative \\
\hline & VU-SCC- $1131^{\ddagger}$ & Female & $\mathrm{T} 4 \mathrm{~N} 2 \mathrm{~b}$ & Floor of mouth & Negative \\
\hline
\end{tabular}

NA- not annotated. a TP53 wild-type cell line. b Cell lines from a sporadic HNSCC tumor with a de novo Fanconi gene mutation (16). $¥$ Local recurrences of primary tumor.

\section{Cell line secretome collection}

Conditioned medium from cell lines was collected and processed as described before (17). Briefly, cells were seeded in T175 flasks and cultured until 70\% confluence. Cells were subsequently washed three times with PBS and incubated for $24 \mathrm{~h}$ in serum-free medium prior to harvest of the conditioned medium. Following centrifugation ( $5 \mathrm{~min}$ at $500 \mathrm{x} \mathrm{g}$ ) and passing of the supernatant over a $0.45 \mu \mathrm{m}$ filter for removal of cell debris, the medium was concentrated to $200 \mu \mathrm{l}$ using an Amicon $3 \mathrm{kDa}$ filter (Merck Millipore). Protein concentration determination performed using BCA Protein Assay Kit (Pierce, Thermo Scientific). Following addition of LDS Sample Buffer (Invitrogen) containing $100 \mathrm{mM}$ dithiothreitol, $30 \mu \mathrm{g}$ of secreted protein lysate were separated using gel electrophoresis.

\section{Protein gel electrophoresis of tissue lysates and cell line secretomes and in-gel digestion}

Prior to mass-spectrometry analysis, proteins were fractionated by gel electrophoresis followed by coomassie staining. Gel electrophoresis and in-gel digestion were done as described earlier (17). Tissue lysates $(25 \mathrm{ml})$ were separated on a $12 \%$ SDS-PAGE acrylamide (BioRad, Hercules, CA), at $100 \mathrm{~V}$ until the sample had entered just into the running gel. The cell line secretomes were separated until the bromophenol-blue dye-front reached the end of the running gel. Following electrophoresis, gels were fixed in $3 \%$ phosphoric acid/50\% ethanol solution, stained with blue G-250 Coomassie brilliant and then washed twice in $50 \mathrm{mM} \mathrm{ABC}$, twice in $50 \mathrm{mM} \mathrm{ABC} / 50 \% \mathrm{ACN}$ and once in $50 \mathrm{mM} \mathrm{ABC}$. Gels bands (tissue lysate) were cut into $1 \mathrm{~mm}^{3}$ cubes. The lane for each secretome was cut into 5 fractions and each fraction was cut into $\sim 1 \mathrm{~mm}^{3}$ cubes. Gel cubes were reduced in $10 \mathrm{mM} \mathrm{DTT/50} \mathrm{mM} \mathrm{ABC} \mathrm{for} 1$ hour at $56{ }^{\circ} \mathrm{C}$ and alkylated in 50 $\mathrm{mM}$ iodoacetamide for 45 minutes at room temperature in the dark. After washing in $50 \mathrm{mM} \mathrm{ABC} / 50 \%$ ACN, gel cubes were dried in vacuum centrifuge for 10 minutes at $50^{\circ} \mathrm{C}$. Following gel cube rehydration by trypsin solution (Promega, $6.25 \mathrm{ng} / \mathrm{mL}$ in $50 \mathrm{mM} \mathrm{ABC}$ ), the gel cubes were covered with $50 \mathrm{mM} A B C$ and incubated overnight at $25^{\circ} \mathrm{C}$. Peptides were isolated from the gel cubes with $5 \%$ FA/50\% ACN (twice) and $1 \%$ formic acid (FA) (once). In a vacuum centrifuge at $60{ }^{\circ} \mathrm{C}$ the extracts were concentrated before LC-MS/MS after which volumes were adjusted to $50 \mu \mathrm{l}$ with $0.05 \%$ FA into LC autosampler vials after filtering through spin filter of $0.45 \mu \mathrm{m}(18)$.

\section{NanoLC-MS/MS proteomic analysis}

NanoLC-MS/MS measurement was performed as described previously (19). Peptides were separated using an Ultimate 3000 nanoLC-MS/MS system (Dionex LC-Packings, Amsterdam, The Netherlands) equipped with a $40 \mathrm{~cm} \times 75 \mu \mathrm{m}$ ID fused silica column custom packed with $1.9 \mu \mathrm{m} 120 \AA \AA$ ReproSil Pur C18 aqua (Dr Maisch GMBH, Ammerbuch-Entringen, Germany). After injection, peptides were trapped at $10 \mu \mathrm{l} / \mathrm{min}$ on a $10 \mathrm{~mm} \times 100 \mu \mathrm{m}$ ID trap column packed with 5 $\mu \mathrm{m} 120 \AA$ ReproSil Pur C18 aqua in buffer A (buffer A: 0.1\% formic acid in MQ; buffer B: $80 \% \mathrm{ACN}+0.1 \%$ formic acid in MQ) and separated at $300 \mathrm{nl} / \mathrm{min}$ in a $10-40 \%$ buffer $B$ gradient in $90 \mathrm{~min}$ ( $130 \mathrm{~min}$ inject-to-inject) at $35^{\circ} \mathrm{C}$. Eluting peptides were ionized at a potential of $+2 \mathrm{kVa}$ into a $\mathrm{Q}$ Exactive mass spectrometer (Thermo Fisher, Bremen, Germany). Intact peptide masses were measured at resolution 70.000 (at $\mathrm{m} / \mathrm{z} 200$ ) in the orbitrap using an AGC target value of $3 \times 10^{6}$ charges. The top 10 peptide signals (charge-states $2^{+}$and higher) were submitted to MS/MS In the HCD (higher-energy collision) cell ( $1.6 \mathrm{~m} / \mathrm{z}$ isolation width, $25 \%$ normalized collision energy) using an AGC target value of $1 \times 10^{6}$ charges an underfill ratio of $0.5 \%$ and a maxIT of 60 ms at resolution 17.500 (at m/z 200). Dynamic exclusion was applied with a repeat count of 1 and an exclusion time of $30 \mathrm{~s}$. Each biological sample was injected twice and the LC-MS raw files for each sample were combined in the database search.

Page $4 / 12$ 
OSCC MS/MS spectra were searched against the Swissprot human reference proteome FASTA file (canonical and isoforms) downloaded February 2019 (42417 entries) using MaxQuant 1.6.4.0. HNSCC MS/MS spectra were searched against the Swissprot human reference proteome FASTA file (canonical and isoforms) downloaded January 2018 (42258 entries) using MaxQuant 1.6.0.16(20). Two missed cleavages were allowed, and specificity of enzyme was set to trypsin. Methionine oxidation (Met, $+15.994915 \mathrm{Da}$ ) and $\mathrm{N}$-terminal acetylation ( $\mathrm{N}$-terminal, $+42.010565 \mathrm{Da}$ ) was treated as variable modifications and Cysteine carboxamidomethylation (Cys, $+57.021464 \mathrm{Da}$ ) as fixed modification. Intact peptide ions were searched with a maximum mass deviation of $4.5 \mathrm{ppm}$ and fragment ions with a maximum mass deviation of 20 ppm, (default MaxQuant settings). Using the target/decoy database search technique, peptide and protein identifications were filtered at an FDR of 1 percent. Proteins that could not be differentiated based on MS/MS spectra alone were grouped to protein groups (default MaxQuant settings).

\section{Protein quantitation and differential analysis}

Spectral counting quantification of proteins was used, that is the sum of all MS/MS spectra for every detected protein (21). Spectral counts for known proteins in a sample were normalized to the sum of spectral counts for that sample and subsequently multiplied by the mean of the sum for all samples. This procedure gives the relative spectral count contribution of a protein to all spectral counts in the sample. The normalized spectral counts were used to calculate the ratio of different biological sample groups. In that manner, we were able to correct for loading differences between samples. Differential analysis of samples was done using the beta-binominal test (17), which considers within- and between-sample variations. Cluster analyses of differentially expressed proteins were performed using hierarchical clustering in $\mathrm{R}$, in which the protein abundances were normalized to zero mean and unit variance. For protein clustering, the Euclidean distance was used. The mass spectrometry proteomics data have been deposited to the Proteome Xchange Consortium via the PRIDE (http:// proteomecentral.proteomexchange.org/) (22) partner repository with the dataset identifier PXD025701.

\section{Data mining, visualization \& network analysis}

The "protein-protein interaction network" analysis of up-regulated proteins in OSCC was performed using tool STRING, version 10.5 (23) with medium stringency and default settings. The edges represent protein-protein interactions and nodes denote proteins based on different levels of evidence collected by String, and also visualized using MCL-cluster plugin of Cytoscape version 3.4.1 (24). Gene ontology analysis was performed using the ClueGO app to get biological processes overrepresented and proteins involved [32] with cut-off $0.01 \mathrm{p}$-value. GSEA analysis was done using -log10 p value combined with FC values as the ranking metric (25) to identify GO-biological-processes enriched for high and low expression proteins. Expression plots were made in R. TFs which are responsible for regulating the expression of many of genes that mediate their biological activities like induction of cell-cycle arrest and apoptosis were identified using iRegulon (26). The set criteria for motif enrichment analysis was as follows: FDR on motif similarity $\leq 0.001$, identity between orthologous genes $\geq 0.0$, and TF motifs with normalized enrichment score (NES) \& gt; 3 . The ranking preference for Motif collection was fixed to a putative regulatory region of $20 \mathrm{~kb}$ centered on TSS (7 species) and $10 \mathrm{~K}$ (9713 PWMs) was selected for the analysis. Thereafter, TF-target pairs were found based on the databases like TRANSFAC comprised in the iRegulon plugin. To predicted non-classically and classically secreted proteins SignalP 5.0/SecretomeP 2.0 Server were used, whereby the signal peptide's presence in the sequence of protein was used to categorize it as classically secreted and the threshold of NN score $\geq 0.6$ and no existence of a signal peptide to categorize it as non-classically secreted proteins (27).

\section{Results And Discussion}

\section{Protein profiling of OSCC tissue vs NAT lysates}

To identify altered biology and candidate biomarkers for OSCC, we performed mass spectrometry-based proteomics of cancer and adjacent normal tissues of 14 patients. For optimal label-free protein comparison, we ensured equal protein amounts loaded on the gels (Additional file 1: Fig. S1). In total, 5,123 proteins were identified (Additional file 2: Table S1). About 3104 proteins were identified per sample. First, to get an overview of altered biology, we used GSEA. This analysis revealed that secretion was the most significant increased pathway and myogenesis the most decreased pathway (Fig. 1A). The latter may indicate a mucosa sample contamination artifact underscoring a focus on cancer-associated proteins.

\section{Up Regulated protein networks associated with OSCC}

To study which proteins and pathways were associated with OSCC tissues, we performed differential analysis. A total of 205 up regulated proteins (Additional file 3: Table S2) were significantly differentially expressed ( $p<0.01,2$-fold up).

To gain further insight into the tumor biology, we generated a protein-protein interaction network for the 205 upregulated proteins in OSSC and found high connectivity with several tightly connected clusters (Fig. 2a, b, Additional file 4: Table S3). The 6 major clusters were enriched for proteins involved in secretory pathway (Cluster 1), spliceosomal complex assembly (Cluster 2), protein localization to endosome (Clusters 3 ), immunity (cluster 5 ) and protein biosynthesis (cluster 6).

Importantly, cancer cells are known to exhibit altered protein secretion to create a favorable tumor microenvironment (28). The up regulation of the secretory pathway may indicate that OSCC tissues secrete more proteins compared to normal tissues. Furthermore, secreted proteins may also be used as non-invasive biomarkers, since they can be secreted into biofluids, including blood or saliva. In addition, the enrichment of biosynthesis pathways of aminoacyl tRNA may also be involved in cancer or/and progression. Aminoacyl tRNA synthetases (ARSs) are vital enzymes that activate amino acids to their related tRNA. Beyond ARSs central role in translation, current studies have discovered their non-translational functions and have additionally associated them to the prognosis of cancer $(29,30)$. For example, in cancer cells inducde by TNF, human lysyl-tRNA synthetase (KARS) is secreted and triggers proinflammatory signaling in immune cells (31). Furthermore, tRNAs can also be secreted, either soluble or via exosomes (32). 
To predict the coordinated regulation of the proteins involved in the differential protein secretion and other biological processes associated with the highly connected protein clusters 1 to 6 (Fig. 2a), we analyzed whether specific transcription factors can regulate these proteins (Table 3 ). Transcription factor binding motifs were predicted in Cytoscape using iRegulon plugin (version 1.3) (26). We used proteins from cluster 1 to 6 as input proteins for motif and track search in the cis-regulatory control elements of genes of those proteins.

Table 3 List of Transcription factors responsible for different biological processes, and the proteins that are identified in the Secretomes of HNSCC cells

\begin{tabular}{|c|c|c|c|c|}
\hline $\begin{array}{l}\text { Serial. } \\
\text { No. }\end{array}$ & $\begin{array}{l}\text { Most connected } \\
\text { biological } \\
\text { network Clusters }\end{array}$ & Target Genes/Proteins & $\begin{array}{l}\text { Transcription } \\
\text { factors by } \\
\text { iRegulon }\end{array}$ & $\begin{array}{l}\text { Proteins Secreted in cell line HNSCC } \\
\text { secretomes }\end{array}$ \\
\hline 1 & $\begin{array}{l}\text { Secretory } \\
\text { Pathway }\end{array}$ & $\begin{array}{l}\text { KLC1, LMAN2, SEC24C, SEC23A, SEC23B, SEC16A, SEC13, } \\
\text { TFG, SEC24D, EML4, COPB1, COPB2, GOLGB1, COPA, } \\
\text { LMAN1, SEC23IP, SURF4, COPG1 }\end{array}$ & Creb3L1 & $\begin{array}{l}\text { LMAN2, SEC24C, SEC23A, SEC23B, SEC13, } \\
\text { TFG, SEC24D, EML4, COPB1, COPB2, } \\
\text { GOLGB1, COPA, LMAN1, COPG1 }\end{array}$ \\
\hline 2 & $\begin{array}{l}\text { Spliceosomal } \\
\text { complex } \\
\text { assembly }\end{array}$ & [SF3B1, SNRNP200, SRSF1, SRSF9] & ESSRA & [SF3B1, SNRNP200, SRSF1, SRSF9] \\
\hline 3 & $\begin{array}{l}\text { Protein } \\
\text { localization to } \\
\text { Endosome }\end{array}$ & [PACSIN2, RAB35, VPS35] & YY & [PACSIN2, VPS35] \\
\hline 4 & $\begin{array}{l}\text { tRNA } \\
\text { aminoacylation } \\
\text { for protein } \\
\text { translation }\end{array}$ & [AARS1, CARS1, EPRS1, LARS1] & ELF2 & [AARS1, CARS1, LARS1] \\
\hline 5 & $\begin{array}{l}\text { Type I interferon } \\
\text { pathway/viral } \\
\text { process }\end{array}$ & [ADAR, EIF2AK2, IFI16, MX1, OAS2, PLSCR1, STAT1] & STAT1 & [ADAR, EIF2AK2, STAT1] \\
\hline 6 & $\begin{array}{l}\text { IRE1-mediate } \\
\text { unfolded protein } \\
\text { response }\end{array}$ & [DNAJB11, DNAJC3, PDIA5] & XBP1 & [DNAJB11, DNAJC3] \\
\hline
\end{tabular}

We found that Creb3/Creb3L1, ESRRA, YY, ELF2, STAT and XBP1 were the central transcription factors that can regulate the highly connected upregulated cluster-proteins. These TFs were previously reported to be upregulated in oral cancer (33-36) (37-40). Targeting these TFs may alter the expression of many proteins.

SecretomeP/SignalP analysis and OSCC tissue and HNSCC cell line secretome protein annotation of subcellular localization

To further explore the process of secretion, we determined which of the deregulated tissue proteins are predicted to have a signal peptide using the SignalP database (27). To gain more insight in the presumed subcellular localization of the proteins, their annotation of subcellular localization was retrieved from the IPA database (Ingenuity ${ }^{\circledR}$ Systems www.ingenuity.com). Interestingly, when looking at the 205 differentially expressed proteins ( $p<.01$ ) of 0 SCC tissue vs. NATs, $37 \%$ of the proteins were predicted to be secreted via classical or non-classical secretion mechanisms (Fig. 4A). Overall, the proportion of proteins from the different subcellular origins was comparable between the OSCC tissue vs. NATs samples and the proportion of cytoplasmic proteins ( $₫ 50 \%$ ) was much higher in OSCC tissues (Fig. 4B,C).

\section{Protein profiling of HNSCC cell line Secretomes and comparison to OSCC tissue}

Biological annotation revealed that the secretome pathway was highly enriched in OSCC tissues.

To further explore the potential of the secretome and annotate OSCC-associated proteins as candidate biofluid markers, we performed LC-MS/MS proteomics on the secretomes of HNSCC cell lines. We selected a diverse panel of $09 \mathrm{Head}$ and neck cancer cell lines to capture the complex tumor biology as much as possible. Cancer-associated proteins that are released may be more likely to be detectable in body fluids like saliva (41). Using an in-depth workflow based on gel fractionation coupled to nanoLC-MS/MS (42), we profiled the secretomes of HNSCC cell lines (Table 2). Prior to mass-spectrometry analysis, input quantities were checked by Coomassie-stained SDS-gel (Additional file 1: Fig. S2).

A total of 4472 cancer cell secretome proteins were identified (Additional file 5: Table S4), of which on average 3500 proteins per sample. Of these, 1724 secretome proteins were identified ( $₫ 5$ average counts) in all HNSCC secretomes (Additional file 6: Table S5). Overlap analysis of these robustly identified secretome proteins with the differential OSCC tissue proteins revealed 132 promising OSCC proteins as candidate non-invasive markers. Underscoring their value as potential OSCC marker, 131 proteins were also cancer-associated in the large-scale proteomics analysis of OSCC tissue recently reported by Huang et al. 2021 (Additional file 7: Table S6). (6) In our list of most overexpressed protein in OSCC tissue or HNSCC secretomes, transferrin receptor (TFRC) was the most differentially expressed protein in tumors as compared to normal. Human Protein Atlas data expression of TFRC is high in HNSCC and it is also found abundant across different cancers, indicating that this is a common protein involved in multiple cancers. TFRC plays essential role in the cellular uptake of iron. TFRC is related to lysosomes/endosomes, which can be secreted into saliva and blood (Additional file 1: Fig. S3a-c). In previous studies, TFRC expression rate in OSCC was found to be substantially higher than in dysplasia, implying that the progression of OSCC disease may be linked to the expression of TFRC. 
(43) Interestingly, functional analysis in vitro and in vivo showed that an anti-TFRC antibody blocking the interaction between transferrin and TFRC and consequently inhibiting iron uptake, lead to the suppression of cell growth and induced apoptosis via iron deprivation.(43) Altogether the results of us and others suggest that TFRC may serve as a promising, cancer biology-linked marker for non-invasive diagnostics in OSCC.

Strikingly, only $23 \%$ of the 132 overlapping OSCC tissue and HNSCC secretome candidates had a predicted signal peptide in their sequence (Fig. 3a-d, Additional file 8: Table S7). 77\% of the proteins did not contain a classical signal peptide but were predicted to be secreted via non-classical routes, as predicted by the SecretomeP algorithm, which is based on other sequence-derived features and their subcellular localization (27). Remarkably, among the proteins significantly more abundant in the HNSCC cell lines secretomes, the proportion of nuclear proteins was $30 \%$. These secretory proteins might serve as non-invasive biomarkers.

\section{Promising candidate biomarker for distinct clinical applications}

Non-invasive detection of OSCC would improve its diagnosis. Therefore, we further annotated the 132 promising proteins from our OSCC tissue proteome ( $\mathrm{p}<$ 0.01 ; $>2$ upregulated) that are likely to be secreted (identified in all 9 cancer cell line secretomes with an average abundance of $>5$ counts), for their potential use as non-invasive biomarker. To this end, we explored detectability in public proteomics datasets; salivary proteome healthy vs. OSCC dataset by Chu et al., 2019 (7), human salivary proteome by P. Sivadasan et al., 2015 (8) and Normal Saliva Proteome database (https://salivaryproteome.nidcr.nih.gov/) (Additional file 9: Table S8). Importantly, 106 out of our 132 candidates (Fig. 4, Additional file 10: Table S9), potential OSCC biofluid markers were also identified in the saliva proteome, with 25 top candidates detected in all 3 studies (Table 3 ). Therefore, these proteins may have the potential to be further exploited for developing a non-invasive biomarker test for the early detection or prognosis of OSCC. THBS2, LGALS3BP and DNAJB11 were potentially useful salivary markers for the detection of OSCC as reported previously $(41,44-46)$.

\section{Conclusions}

In conclusion, using comparative analysis of matched OSCC and normal tissues we identified key deregulated proteins consisting of highly connected biological networks associated to distinct functional pathways, which may contribute to pathogenesis. Bioinformatics and overlap with cancer cell secretome and public saliva data identified key OSCC proteins involved in secretory pathways and potential non-invasive biomarkers to explore for their ability to detect OSCC at an early stage. Protein TFRC the most upregulated in OSCC cancer tissues and identified in all cancer cell secretomes previously not reported, is an especially promising candidate non-invasive biomarker that should be further evaluated for their potential for the early detection of OSCC.

\section{Abbreviations}

Normal Adjacent Tissue (NAT), Oral Squamous Cell Carcinomas (OSCC), Head and Neck Squamous Cell Carcinoma (HNSCC), Liquid chromatography-mass spectrometry (LC-MS/MS), Gene Set Enrichment Analysis (GSEA), Gene ontology (GO), Differentially expressed Proteins (DEPs), Fold Changes (FCs), Transcription Factors (TFs)

\section{Declarations}

\section{Authors' contributions}

Madiha Mumtaz: Conceptualization, Methodology, Investigation Writing- Original draft preparation - Editing, Irene V Bijnsdorp: technical support, acquisition of data, drafting of manuscript, Franziska Böttger: HNSCC cell lines, Sander R. Piersma: Mass Spec Investigation, Thang V. Pham: Statistical analysis, Visualization, Samiullah: Tissues sample and patient data collection, manuscript writing, Ruud H. Brakenhoff: HNSCC cell lines, M Waheed Akhtar: Conceptualization, contributed to supervision, administrative, technical, or material support, Connie R. Jimenez: contributed to supervision, administrative, technical, or material support, Reviewing and Editing. All authors read and approved the final manuscript.

\section{Funding}

This work was supported by a research grant, from the Higher Education Commission, Pakistan.

\section{Acknowledgements}

All the authors are grateful to the surgeons of Mayo and Jinnah Hospitals, Lahore, Pakistan for their help in the sample collection. VUmc-Cancer Center Amsterdam is acknowledged for support of the proteomics infrastructure.

\section{Competing interests}

The authors declare that they have no competing interests.

\section{Availability of data and materials}

The datasets generated or analyzed during the current study are available from the corresponding author on reasonable request.

\section{Consent for publication}

All authors consent to the publication of this manuscript. 


\section{Ethics approval and consent to participate}

All patients or legal guardians consented to participation in the study in accordance with by the Institutional Ethical Review Board, King Edward Medical University [Ref. No. 306/RC/KEMU].

\section{References}

1. Bray F, Ferlay J, Soerjomataram I, Siegel RL, Torre LA, Jemal A. Global cancer statistics 2018: GLOBOCAN estimates of incidence and mortality worldwide for 36 cancers in 185 countries. CA: a cancer journal for clinicians. 2018;68(6):394-424.

2. Khan MA, Saleem S, Shahid SM, Hameed A, Qureshi NR, Abbasi Z, et al., editors. Prevalence of oral squamous cell carcinoma ( OSCC ) in relation to different chewing habits in Karachi , Pakistan2012.

3. Rodriguez H, Zenklusen JC, Staudt LM, Doroshow JH, Lowy DR. The next horizon in precision oncology: Proteogenomics to inform cancer diagnosis and treatment. Cell. 2021;184(7):1661-70.

4. Fijneman RJ, de Wit M, Pourghiasian M, Piersma SR, Pham TV, Warmoes MO, et al. Proximal fluid proteome profiling of mouse colon tumors reveals biomarkers for early diagnosis of human colorectal cancer. Clinical cancer research : an official journal of the American Association for Cancer Research. 2012;18(9):2613-24.

5. Kulasingam V, Diamandis EP. Strategies for discovering novel cancer biomarkers through utilization of emerging technologies. Nature clinical practice Oncology. 2008;5(10):588-99.

6. Huang C, Chen L, Savage SR, Eguez RV, Dou Y, Li Y, et al. Proteogenomic insights into the biology and treatment of HPV-negative head and neck squamous cell carcinoma. Cancer cell. 2021;39(3):361-79.e16.

7. Chu HW, Chang KP, Hsu CW, Chang IY, Liu HP, Chen YT, et al. Identification of Salivary Biomarkers for Oral Cancer Detection with Untargeted and Targeted Quantitative Proteomics Approaches. Molecular \& cellular proteomics : MCP. 2019;18(9):1796-806.

8. Sivadasan P, Gupta MK, Sathe GJ, Balakrishnan L, Palit P, Gowda H, et al. Human salivary proteome-a resource of potential biomarkers for oral cancer. Journal of proteomics. 2015;127(Pt A):89-95.

9. Ghazanfar S, Fatima I, Aslam M, Musharraf SG, Sherman NE, Moskaluk C, et al. Identification of actin beta-like 2 (ACTBL2) as novel, upregulated protein in colorectal cancer. Journal of proteomics. 2017;152:33-40.

10. Bradford MM. A rapid and sensitive method for the quantitation of microgram quantities of protein utilizing the principle of protein-dye binding. Analytical biochemistry. 1976;72:248-54.

11. Nagel R, Clijsters L, Agami R. The miRNA-192/194 cluster regulates the Period gene family and the circadian clock. The FEBS journal. 2009;276(19):544755.

12. Lin CJ, Grandis JR, Carey TE, Gollin SM, Whiteside TL, Koch WM, et al. Head and neck squamous cell carcinoma cell lines: established models and rationale for selection. Head \& neck. 2007;29(2):163-88.

13. Hermsen MA, Joenje H, Arwert F, Welters MJ, Braakhuis BJ, Bagnay M, et al. Centromeric breakage as a major cause of cytogenetic abnormalities in oral squamous cell carcinoma. Genes, chromosomes \& cancer. 1996;15(1):1-9.

14. van Zeeburg HJ, Snijders PJ, Pals G, Hermsen MA, Rooimans MA, Bagby G, et al. Generation and molecular characterization of head and neck squamous cell lines of fanconi anemia patients. Cancer research. 2005;65(4):1271-6.

15. Smeets SJ, Hesselink AT, Speel EJ, Haesevoets A, Snijders PJ, Pawlita M, et al. A novel algorithm for reliable detection of human papillomavirus in paraffin embedded head and neck cancer specimen. International journal of cancer. 2007;121(11):2465-72.

16. Stoepker C, Ameziane N, van der Lelij P, Kooi IE, Oostra AB, Rooimans MA, et al. Defects in the Fanconi Anemia Pathway and Chromatid Cohesion in Head and Neck Cancer. Cancer research. 2015;75(17):3543-53.

17. Piersma SR, Fiedler U, Span S, Lingnau A, Pham TV, Hoffmann S, et al. Workflow comparison for label-free, quantitative secretome proteomics for cancer biomarker discovery: method evaluation, differential analysis, and verification in serum. Journal of proteome research. 2010;9(4):1913-22.

18. Piersma SR, Knol JC, de Reus I, Labots M, Sampadi BK, Pham TV, et al. Feasibility of label-free phosphoproteomics and application to base-line signaling of colorectal cancer cell lines. Journal of proteomics. 2015;127(Pt B):247-58.

19. de Wit M, Kant H, Piersma SR, Pham TV, Mongera S, van Berkel MP, et al. Colorectal cancer candidate biomarkers identified by tissue secretome proteome profiling. Journal of proteomics. 2014;99:26-39.

20. Cox J, Mann M. MaxQuant enables high peptide identification rates, individualized p.p.b.-range mass accuracies and proteome-wide protein quantification. Nature biotechnology. 2008;26(12):1367-72.

21. Liu H, Sadygov RG, Yates JR, 3rd. A model for random sampling and estimation of relative protein abundance in shotgun proteomics. Analytical chemistry. 2004;76(14):4193-201.

22. Perez-Riverol Y, Csordas A, Bai J, Bernal-Llinares M, Hewapathirana S, Kundu DJ, et al. The PRIDE database and related tools and resources in 2019: improving support for quantification data. Nucleic acids research. 2019;47(D1):D442-d50.

23. Szklarczyk D, Franceschini A, Wyder S, Forslund K, Heller D, Huerta-Cepas J, et al. STRING v10: protein-protein interaction networks, integrated over the tree of life. Nucleic acids research. 2015;43(Database issue):D447-52.

24. Lopes CT, Franz M, Kazi F, Donaldson SL, Morris Q, Bader GD. Cytoscape Web: an interactive web-based network browser. Bioinformatics (Oxford, England). 2010;26(18):2347-8. 
25. Liao Y, Wang J, Jaehnig EJ, Shi Z, Zhang B. WebGestalt 2019: gene set analysis toolkit with revamped Uls and APIs. Nucleic acids research. 2019;47(W1):W199-w205.

26. Janky R, Verfaillie A, Imrichová H, Van de Sande B, Standaert L, Christiaens V, et al. iRegulon: from a gene list to a gene regulatory network using large motif and track collections. PLoS computational biology. 2014;10(7):e1003731.

27. Bendtsen JD, Jensen LJ, Blom N, Von Heijne G, Brunak S. Feature-based prediction of non-classical and leaderless protein secretion. Protein engineering, design \& selection : PEDS. 2004;17(4):349-56.

28. da Cunha BR, Domingos C, Stefanini ACB, Henrique T, Polachini GM, Castelo-Branco P, et al. Cellular Interactions in the Tumor Microenvironment: The Role of Secretome. Journal of Cancer. 2019;10(19):4574-87.

29. Guo M, Schimmel P. Essential nontranslational functions of tRNA synthetases. Nature chemical biology. 2013;9(3):145-53.

30. Kim D, Kwon NH, Kim S. Association of aminoacyl-tRNA synthetases with cancer. Topics in current chemistry. 2014;344:207-45.

31. Park SG, Kim HJ, Min YH, Choi EC, Shin YK, Park BJ, et al. Human lysyl-tRNA synthetase is secreted to trigger proinflammatory response. Proceedings of the National Academy of Sciences of the United States of America. 2005;102(18):6356-61.

32. Kim SB, Kim HR, Park MC, Cho S, Goughnour PC, Han D, et al. Caspase-8 controls the secretion of inflammatory lysyl-tRNA synthetase in exosomes from cancer cells. The Journal of cell biology. 2017;216(7):2201-16.

33. Claerhout S, Dutta B, Bossuyt W, Zhang F, Nguyen-Charles C, Dennison JB, et al. Abortive autophagy induces endoplasmic reticulum stress and cell death in cancer cells. PloS one. 2012;7(6):e39400.

34. Chen H, Li K, Li Y, Xie P, He J, Zhang H. An integrative pan-cancer analysis of COPB1 based on data mining. Cancer biomarkers : section A of Disease markers. 2021;30(1):13-27.

35. Colella G, Izzo G, Carinci F, Campisi G, Lo Muzio L, D'Amato S, et al. Expression of sexual hormones receptors in oral squamous cell carcinoma. International journal of immunopathology and pharmacology. 2011;24(2 Suppl):129-32.

36. Schnoell J, Jank BJ, Kadletz-Wanke L, Stoiber S, Spielvogel CP, Gurnhofer E, et al. Transcription factors CP2 and YY1 as prognostic markers in head and neck squamous cell carcinoma: analysis of The Cancer Genome Atlas and a second independent cohort. Journal of cancer research and clinical oncology. 2021;147(3):755-65.

37. Chung IH, Liu H, Lin YH, Chi HC, Huang YH, Yang CC, et al. ChIP-on-chip analysis of thyroid hormone-regulated genes and their physiological significance. Oncotarget. 2016;7(16):22448-59.

38. Liu Y, Tao Z, Qu J, Zhou X, Zhang C. Long non-coding RNA PCAT7 regulates ELF2 signaling through inhibition of miR-134-5p in nasopharyngeal carcinoma. Biochemical and biophysical research communications. 2017;491(2):374-81.

39. Rao SK, Pavicevic Z, Du Z, Kim JG, Fan M, Jiao Y, et al. Pro-inflammatory genes as biomarkers and therapeutic targets in oral squamous cell carcinoma. The Journal of biological chemistry. 2010;285(42):32512-21.

40. Denoyelle C, Abou-Rjaily G, Bezrookove V, Verhaegen M, Johnson TM, Fullen DR, et al. Anti-oncogenic role of the endoplasmic reticulum differentially activated by mutations in the MAPK pathway. Nature cell biology. 2006;8(10):1053-63.

41. Hsu CW, Yu JS, Peng PH, Liu SC, Chang YS, Chang KP, et al. Secretome profiling of primary cells reveals that THBS2 is a salivary biomarker of oral cavity squamous cell carcinoma. Journal of proteome research. 2014;13(11):4796-807.

42. Piersma SR, Warmoes MO, de Wit M, de Reus I, Knol JC, Jiménez CR. Whole gel processing procedure for GeLC-MS/MS based proteomics. Proteome science. 2013;11(1):17.

43. Nagai K, Nakahata S, Shimosaki S, Tamura T, Kondo Y, Baba T, et al. Development of a complete human anti-human transferrin receptor $\mathrm{C}$ antibody as a novel marker of oral dysplasia and oral cancer. Cancer medicine. 2014;3(4):1085-99.

44. Wu CC, Chu HW, Hsu CW, Chang KP, Liu HP. Saliva proteome profiling reveals potential salivary biomarkers for detection of oral cavity squamous cell carcinoma. Proteomics. 2015;15(19):3394-404.

45. Singh P, Verma JK, Singh JK. Validation of Salivary Markers, IL-1 $\beta$, IL-8 and Lgals3bp for Detection of Oral Squamous Cell Carcinoma in an Indian Population. Scientific reports. 2020;10(1):7365.

46. Csősz É, Lábiscsák P, Kalló G, Márkus B, Emri M, Szabó A, et al. Proteomics investigation of OSCC-specific salivary biomarkers in a Hungarian population highlights the importance of identification of population-tailored biomarkers. PloS one. 2017;12(5):e0177282.

\section{Figures}




\section{Gene Set Enrichment Analysis (GSEA)}

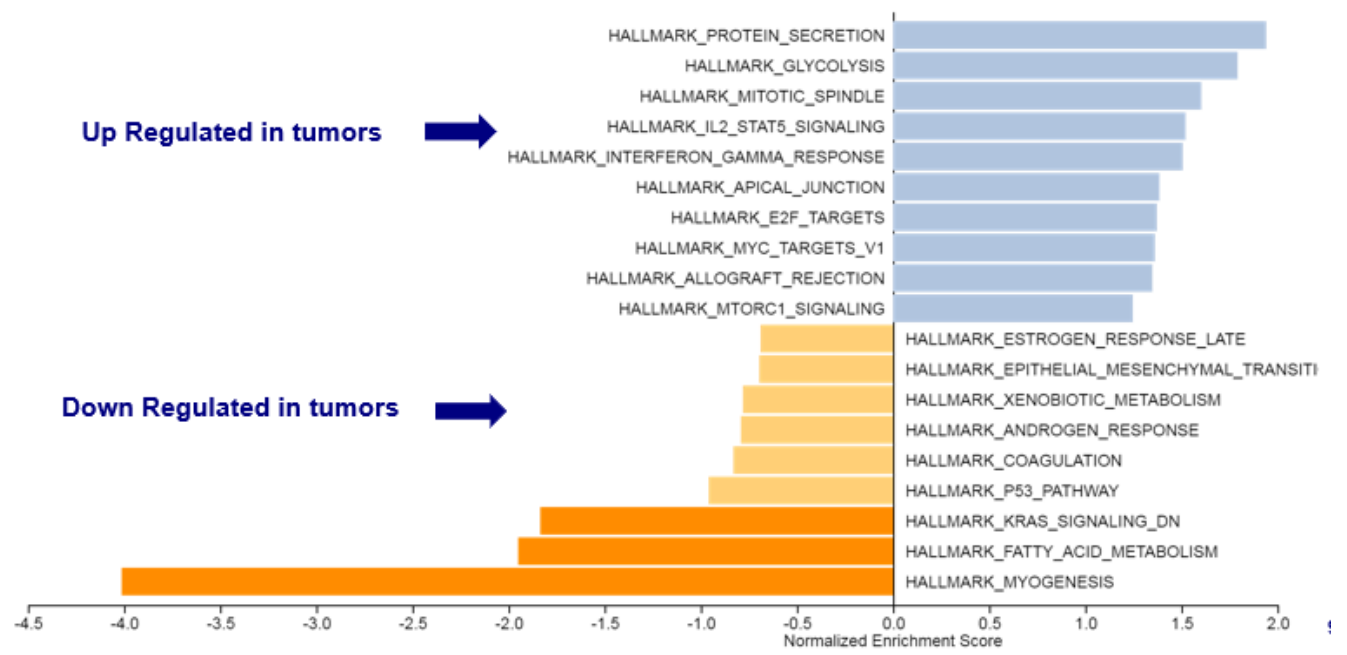

Figure 1

GSEA analysis was done using -log10 p value combined with FCs values as the ranking metric (25) to identify GO-biological-processes enriched for high and low expression proteins. This identified many deregulated biological processes, pathways up and down regulated shown in blue and orange color respectively. If FDR is smaller than or equal to 0.05 , the colors of the bar are darker, while the color for categories with FDR larger than 0.05 is in a lighter shade.

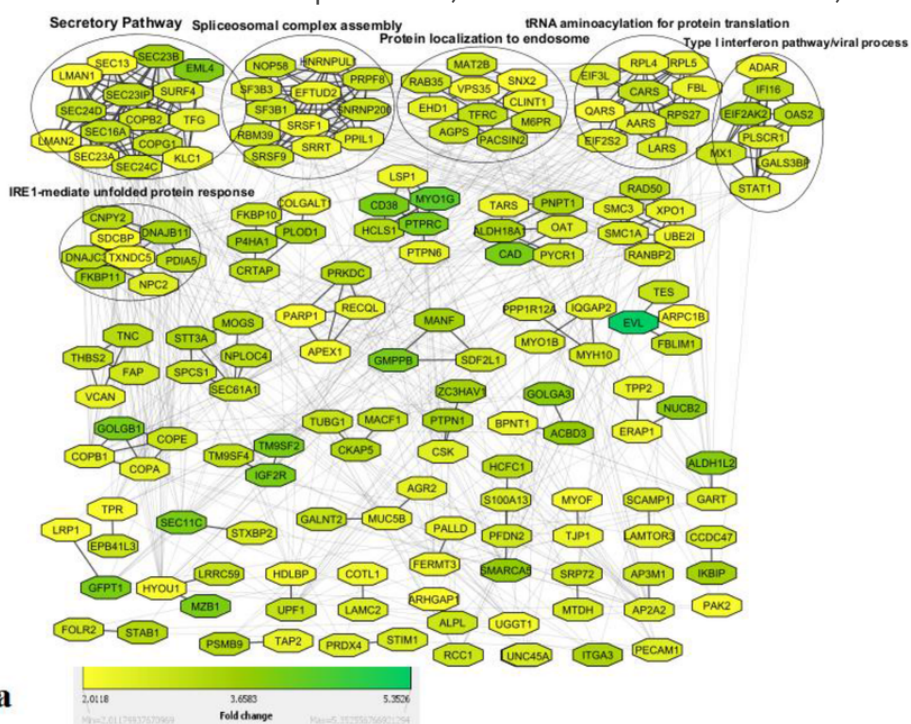

\begin{tabular}{|c|c|c|c|c|c|}
\hline PROCESS & GO TERMS & $\begin{array}{l}\text { TERM P } \\
\text { VALUE }\end{array}$ & $\begin{array}{l}\text { CORRECTED } \\
\text { PVALUE }\end{array}$ & NUMBER OF GENES & CLUSTERS \\
\hline \multirow{4}{*}{ Secretory Pathway } & $\begin{array}{c}\text { Endoplasmic reticulum to Golgi vesicle- } \\
\text { mediated transport }\end{array}$ & $3.12 E-21$ & $1.25 \mathrm{E}-20$ & $\begin{array}{c}\text { [COPB2, COPG1, LMAN1, LMAN2, SEC13, } \\
\text { SEC16A, SEC23A, SEC23B, SEC23IP, SEC24C, } \\
\text { SEC24D, TFG] }\end{array}$ & \multirow{4}{*}{1} \\
\hline & \begin{tabular}{|l|} 
Antigen processing and presentation of \\
exogenous peptide antigen via MHC class \\
II
\end{tabular} & $1.53 \mathrm{E}-08$ & $1.53 \mathrm{E}-08$ & [KLC1, SEC13, SEC23A, SEC24C, SEC24D] & \\
\hline & COPII-coated vesicle cargo loading & $3.83 \mathrm{E}-13$ & $7.67 \mathrm{E}-13$ & [SEC13, SEC23A, SEC23B, SEC24C, SEC24D] & \\
\hline & COPII-coated vesicle cargo budding & $1.30 \mathrm{E}-18$ & $3.90 \mathrm{E}-18$ & $\begin{array}{l}\text { [LMAN1, SEC13, SEC16A, SEC23A, SEC23B, } \\
\text { SEC23IP, SEC24C, SEC24D, TFG] }\end{array}$ & \\
\hline \multirow{2}{*}{$\begin{array}{c}\text { Spliceosomal } \\
\text { complex assembly }\end{array}$} & Spliceosomal complex assembly & $\begin{array}{l}5.44501 \mathrm{E}- \\
08\end{array}$ & $1.089 \mathrm{E}-07$ & [SF3B1, SNRNP200, SRSF1, SRSF9] & \multirow{2}{*}{2} \\
\hline & mRNA cis splicing, via spliceosome & $\begin{array}{l}1.60387 \mathrm{E}- \\
06\end{array}$ & $1.60387 \mathrm{E}-06$ & [SNRNP200, SRSF1, SRSF9] & \\
\hline $\begin{array}{l}\text { Protein localization } \\
\text { to Endosome }\end{array}$ & & 4.50E-07 & 4.50E-07 & [PACSIN2, RAB35, VPS35] & 3 \\
\hline $\begin{array}{c}\text { TRNA } \\
\text { aminoacylation for } \\
\text { protein translation }\end{array}$ & & $8.52 E-09$ & $8.52 \mathrm{E}-09$ & [AARS1, CARS1, EPRS1, LARS1] & 4 \\
\hline \multirow{3}{*}{$\begin{array}{l}\text { Type I interferon } \\
\text { pathway/viral } \\
\text { process }\end{array}$} & Regulation of Viral Genome & $7.99 \mathrm{E}-13$ & $2.40 \mathrm{E}-12$ & [ADAR, EIF2AK2, IF116, MX1, OAS2, PLSCR1] & \multirow{3}{*}{5} \\
\hline & Negative Regulation of Viral Process & $1.01 \mathrm{E}-12$ & $2.02 E-12$ & [EIF2AK2, IF116, MX1, OAS2, PLSCR1, STAT1] & \\
\hline & Type I Interferon Signaling Pathway & $5.26 \mathrm{E}-08$ & $5.26 \mathrm{E}-08$ & [ADAR, MX1, OAS2, STAT1] & \\
\hline $\begin{array}{l}\text { IRE1-mediate } \\
\text { unfolded protein } \\
\text { response }\end{array}$ & & $2.99 E-06$ & $2.99 \mathrm{E}-06$ & [DNAIB11, DNAIC3, PDIA5] & 6 \\
\hline
\end{tabular}

b

Figure 2 
up regulated biological processes associated with OSCC (a) String Interaction of 205 up regulated proteins at FC $\otimes+2$ and $\mathrm{P} \otimes 0.01$ in tumors as compared to NATs, Color intensity indicates fold changes according to the 2-group analysis. (b) Biological processes associated with the most populated protein clusters, analyzed using ClueGO.
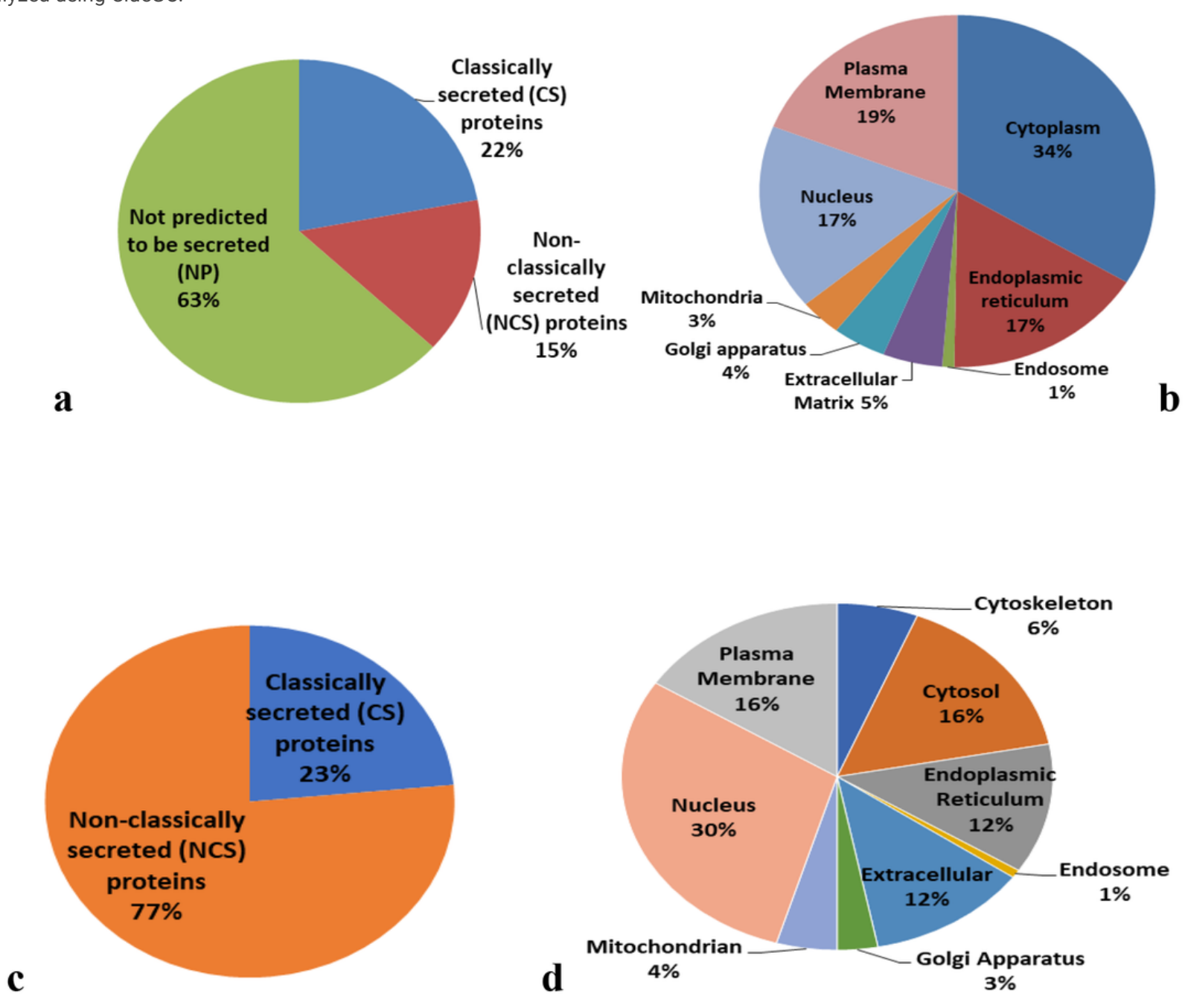

Figure 3

SecretomeP/SignalP analysis gives insight into differential biology of secretion and Proportion of protein subcellular localizations. (a) Percentage of classically secreted (CS) and non-classically secreted (NCS) proteins as well as those not predicted to be secreted (NP) by the SecretomeP algorithm in the OSCC tissue vs. NATs. (b) The pie charts show the percentage of different subcellular localizations of the total differential up regulated proteins in OSCC tissue vs. NATs samples. (c) Percentage of classically secreted (CS) and non-classically secreted (NCS) proteins as well as those not predicted to be secreted (NP) by the SecretomeP algorithm of 132 common identified proteins in the OSCC tissue vs. NATs and secretomes of HNSCC cell lines. (d) The pie charts show the percentage of different subcellular localizations of 132 common identified proteins 


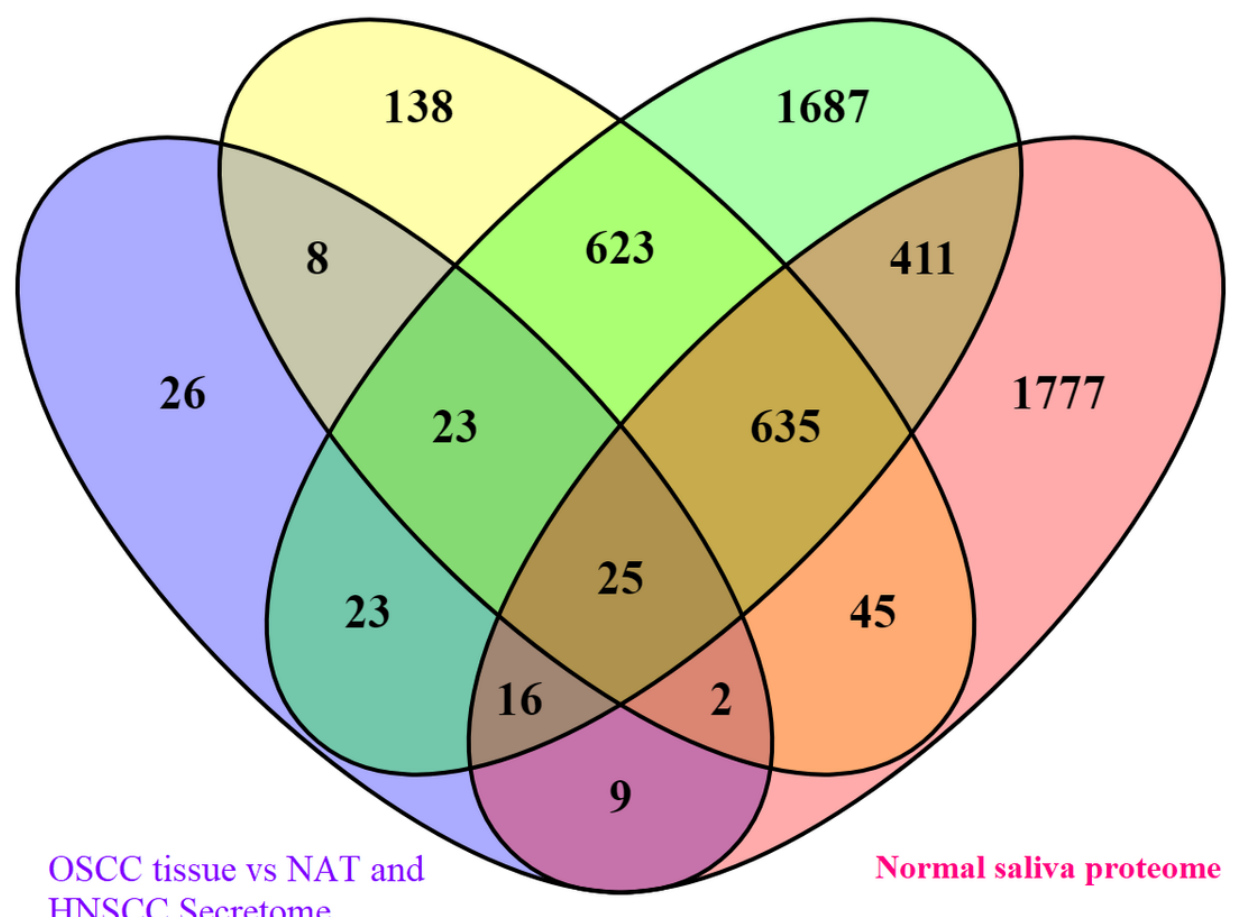

HNSCC Secretome

\section{Figure 4}

Venn diagram showing intersection of OSCC tissues vs. NATs and HNSCC cell line Secretomes and identified proteins in three published salivary datasets, i.e. salivary proteome healthy vs. OSCC dataset by Chu et al., 2019, human salivary proteome (P. Sivadasan et al., 2015) and Normal saliva proteome (https://salivaryproteome.nidcr.nih.gov/).

\section{Supplementary Files}

This is a list of supplementary files associated with this preprint. Click to download.

- Additionalfile1.Supplementryfigures.docx

- Additionalfile2.Tables1.xIsx

- Additionalfile3.Tables2.xIsx

- Additionalfile4.Tables3.xlsx

- Additionalfile5.Tables4.xlsx

- Additionalfile6.Tables5.xlsx

- Additionalfile7.Tables6.xlsx

- Additionalfile8.Tables7.xlsx

- Additionalfile9.Tables8.xlsx

- Additionalfile10.TableS9.xIsx

- Additionalfiles.docx 